\title{
Preface: European large lakes-ecosystem services and management in a changing world
}

\section{The 4th European large lakes symposium}

\author{
Paula Kankaala • Tiina Nõges • Martti Rask • \\ Dietmar Straile $\cdot$ Arkady Terzhevik
}

Published online: 18 August 2016

(C) Springer International Publishing Switzerland 2016

Large lake ecosystems are ecologically, culturally, and economically very important ecosystems providing many valuable services to mankind. Although the large lakes share many common size-related features, the ecosystems also have specific characters due to differences in their geological history, landscape topography, drainage area properties, and regional climatic factors as well as past and present human activities. Thus, the

Guest editors: Paula Kankaala, Tiina Nõges, Martti Rask, Dietmar Straile \& Arkady Yu. Terzhevik / European Large Lakes IV. Ecosystem Services and Management in a Changing World

P. Kankaala $(\square)$

Department of Environmental and Biological Sciences, University of Eastern Finland, Joensuu, Finland

e-mail: paula.kankaala@uef.fi

T. Nõges

Centre for Limnology, Estonian University of Life

Sciences, Rannu, Tartumaa, Estonia

M. Rask

Natural Resources Institute Finland, Jyväskylä, Finland

D. Straile

Limnological Institute, University of Konstanz,

Constance, Germany

A. Terzhevik

Laboratory of Hydrophysics, Russian Academy of

Sciences, Petrozavodsk, Russia biota, ecosystem functions, and services are differently challenged by changing climate, nutrient and organic matter loading, and other anthropogenic factors. Multidisciplinary research and reliable monitoring of the ecological status are essential for planning sustainable use of resources and maintaining ecosystem services of the large lakes. Moreover, many large lakes or their drainage areas are shared by several nations. There has been a long tradition of international co-operation in environmental planning, research, and monitoring of transboundary lakes. Further development of this cooperation is encouraged within the present EU water policy, which calls for the establishing of International River Basin Districts and for the agreement of International River Basin Management Plans.

European Large Lakes Symposia (ELLS) have been a forum for scientists, environmental planners, and authorities from different countries to present research results, advance international co-operation, and develop ideas for improving management of the large lakes. The first symposium took place in 2006 in Tartu, Estonia and was followed by every 3rd year symposia in Norrtälje, Sweden (2009), and Konstanz, Germany (2013). Before these meetings, there had been four International Lake Ladoga Symposia during the years 1992-2002.

The 4th European Large Lakes Symposium (ELLS 2015) was held in Joensuu (University of Eastern Finland) on 24-28 August 2015. The symposium was 
organized by the International Organizing Committee including Dr. Paula Kankaala (Chair, Finland), Dr. Orlane Anneville (France), Prof. Lauri Arvola, (Finland), Dr. Heikki Hämäläinen (Finland), Dr. Marko Järvinen (Finland), Prof. Tiina Nõges, Estonia), Prof. Kurt Pettersson (Sweden), Dr. Martti Rask (Finland), Dr. Nico Salmaso (Italy), Dr. Dietmar Straile (Germany), Dr. Arkady Terzhevik (Russia), and Dr. AnneMari Ventelä (Finland).

The theme of the symposium was Ecosystem Services and Management in a Changing World. The invited keynote lecturers and their topics were as follows:

- Dr. Laurence Carvalho, UK: Putting ecology into ecosystem services: the challenges ahead for lakes research.

- Dr. Seppo Hellstén, Finland: Recent trends and future perspectives in ecological status monitoring of Finnish lakes.

- Prof. Hans. W. Paerl, USA: Controlling a global proliferation of toxic cyanobacterial blooms in large lakes: The case for dual nutrient ( $\mathrm{N} \& \mathrm{P})$ input reduction strategies.

- Dr. Dietmar Straile, Germany: The response of large and deep lakes to climate change.

- Dr. Anne-Mari Ventelä, Finland: Fisheries and climate change.

- Dr. Priit Zingel: Microbial loop in large lakes.

Altogether, 100 participants from 15 countries (Australia, China, Estonia, Finland, France, Germany, Hungary, Iran, Italy, Japan, Russia, Sweden, Ukraine, the UK, and the USA) presented their results in lectures and posters in nine sessions:

- Climate change induced physical and biological responses in large lakes.

- Long-term changes in nutrient and organic matter loading and trophic status of large lakes.

- Ecosystem services of large lakes-more than fishing and recreation.

- Biotic interactions and biodiversity in large lakes.

- Occurrence and impacts of toxic cyanobacteria on the food webs of large lakes.

- Sustainability of ecosystem services and good ecological status in large lakes-challenges for management.

- New tools for monitoring and assessment of ecological status in large lakes.
- Fish and fisheries management in large lakes.

- Emerging contaminants.

Fish and fisheries management proved to be the most popular topic in the symposium program, including 30\% (26/83) of oral and poster presentations, and half of the manuscripts offered for publication in this special issue in Hydrobiologia. This may be an indication of the importance of fisheries as a major ecosystem service provided by large lakes as well as a sign of the need for a special symposium/ series of symposia for large lakes fisheries or freshwater fisheries in general. On the other hand, in a small symposium like ELLS without parallel sessions and covering topics from physics to fisheries, the participants follow the lectures from wide areas, not only focusing on their special field, which is often the case in larger international symposia. This opinion was shared by many 4th ELLS participants.

Although the name and history of ELLS only refer to 'European Large Lakes', there have been participants and presentations dealing with large lakes outside Europe in all these meetings. During the 4th symposium in Finland, an initiative was discussed that future symposia could be organized in co-operation with the International Association for Great Lakes Research (IAGLR), which since 1950's has had a lot of activities including annual conferences in North America. This could raise international visibility and foster interaction, partnership, and collaboration in research and management of large lake environments encountering local and global challenges. This plan has been discussed with the board members of IAGLR, and the next ELLS in 2018 is planned to be a joint meeting together with IAGLR in France, on Lake Geneva.

This special issue of Hydrobiologia presents 12 papers of the presentations given during the 4th ELLS in Joensuu, Finland. The submitted manuscripts (total number 23) were peer reviewed with the criteria used by the journal. Thus, the percentage of accepted manuscripts is $52 \%$.

We thank Maj \& Tor Nessling Foundation, Federation of Finnish Learned Societies and the University of Eastern Finland for financial support for the symposium. We are very thankful to Tuula Toivanen (secretary), Merja Lyytikäinen (web master), and Arja Hukkanen (registration) for all precise help in the arrangements before and during the symposium. We 
also thank volunteer students for their assistance during the symposium. We are thankful to the reviewers of the all manuscripts submitted to this special issue of Hydrobiologia as well as the journal's editor-in-chief Koen Martens and the editorial office assistant Deepan Selvaraj for all the help in editing this issue. 